\title{
The Suppressed Legacy of Nuremberg
}

\author{
by Robert A. Burt
}

\begin{abstract}
The story of patient self-determination cannot be told without the Nuremberg trials. Patient autonomy was the first criterion enunciated by the Nuremberg judges and has served as a touchstone for human subject research and patient care ever since. Yet this ideal was in an important sense irrelevant at the moment it was originally proclaimed.
\end{abstract}

\section{$\mathrm{N}$} uremberg has a special resonance in the annals of law and biomedical ethics. Though it was not the first jurisprudential appearance for the principle of patient autonomy, the Nuremberg judgment gave central importance to this principle as an ideal that should govern physicianpatient relations. When we retell the history of this relationship todayits evolution from "doctor knows best" to "patient self-determination"-honorific citation to Nuremberg is a conventional starting point in the narrative.

Depending on the narrator, there are two typical variations of the story. Most frequently, the plotline is a progression onward and upward for the application of the Nuremberg autonomy ideal: from research subjects to all patients, from the right to "informed choice" about extraordinary therapies to the right to refuse "ordinary" life-prolonging interventions such as tube feeding or antibiotics, from the right to refuse treatment to the right to obtain physician assistance in suicide. ${ }^{1}$ In other, less com-

Robert A. Burt, "The Suppressed Legacy of Nuremberg," Hastings Center Report 26, no. 5 (1996): 30-33. mon, recountings, the plotline puts Nuremberg at a pinnacle followed by decline; in this version, the vision of patient autonomy held aloft by the Nuremberg judges has subsequently been given lip-service but never fully honored in practice. ${ }^{2}$ In either variation, the story has a triumphalist implication-a moral victory was won at Nuremberg and that victory serves as a beacon (or as a righteous rebuke) for us today.

Like many oft-told family stories, however, this narrative has a darker side that the constant retelling obscures and yet, at the same time, paradoxically keeps alive by the simple fact of its repetition. The self-determination ideal is, of course, much celebrated in our political tradition; it was the guiding ideal in this country for our War of Independence from Great Britain. Since that foundational moment, the ambit of this ideal has been a continuously contested proposition. The terms of this contest have had the same recurrent theme: that some social relationships are outside the self-determination ideal and are more properly (or even more "naturally") depicted as based on dependency and correlative inequality between caretaker and ward. This was the argument advanced in the nineteenth century by men of property regarding landless laboring men, by white slaveholders regarding black slaves, by men regarding women, by physicians regarding patients. The case for dependency and inherent inequality has, however, been a losing battle: the dominant narrative in our intellectual history has been the progressive spread of the self-determination ideal as the sole legitimate depiction of all these social relationships (however haltingly or imperfectly that ideal has been implemented in practice).

The application of the ideal to physician-patient relations is the most recent in this progression but it hardly seems surprising; and its invocation in the 1947 doctors' trial at Nuremberg is even less surprising in light of the fact that all of the judges in this proceeding were Americans, whereas the judges in the immediately preceding Nuremberg trials of high Nazi officials and German military officers were drawn from all of the Allied nations. There is, nonetheless, one surprising aspect to the conjuring of the self-determination ideal in the Nuremberg doctors' trial that seems, on close inspection, to raise some disconcerting questions about the legitimacy of its application there.

Consider the foundational example of the self-determination ideal in the American Revolution. In that context, the proponents of the ideal understood that if they had consented to the measures imposed by Great Britain regarding taxation or other matters, their consent in itself would have validated the British actions. At Nuremberg, however, it was clear that the consent of the experimental subjects would not have justified the experiments. The ideal of patient selfdetermination whose lineage is so proudly traced to Nuremberg was in an important sense irrelevant at the very moment that it was originally proclaimed. This is an odd beginning for a family history.

Patient self-determination was the first criterion that the Nuremberg judges enunciated-that "the voluntary consent of the human subject is absolutely essential" ${ }^{3}$-and this selfconsciously awarded pride of place established the central role of the Nuremberg judgment in subsequent recitations of this ideal. But the 
judges also invoked eight other criteria which, they said, "all [medical ethicists] agree ... must be observed" in human experimentation. Only two of these standards dealt with self-determination: the first, as quoted, and the ninth, which specified that the subject must remain free to discontinue the experiment at any time. The other eight criteria all depended, more or less explicitly, on the application of "reasonable professional judgment." The second, for example, provided that "the experiment should be such as to yield fruitful results for the good of society, unprocurable by other methods ... ."; the sixth stated that "the degree of risk to be taken should never exceed that determined by the humanitarian importance of the problem to be solved. ...."

The application of these standards faced a very different direction from the tribunal's initial insistence on patient consent. We have become so accustomed today to the norm of patient consent that we easily miss the disturbing implications of the differing perspectives between this norm and the other criteria in the Nuremberg pantheon. At the moment that the Nuremberg tribunal promulgated these standards, however, the disturbance-an undercurrent of loss and disillusion-was almost impossible to ignore.

We might recapture this sense by imagining that we ourselves had been judges at Nuremberg and that, before writing the ten standards in our formal judgment, we had presided over the 133 days of testimony about the concentration camp experiments. During those 133 days, we would have heard about camp inmates placed in pressure chambers where the simulated altitude was increased until their lungs and other body organs exploded; we would have heard about inmates plunged into ice water clothed in heavy military uniforms, or stripped naked and thrown outdoors in winter temperatures, where they remained (clothed or naked) until they had frozen to death; we would have heard about inmates purposefully burnt or cut by ground glass and left untreated until they died from the infection of their wounds; we would have heard about inmates whose healthy arms or legs were severed simply to test vari- ous surgical techniques for amputations.

After hearing all of this, during more than four months of testimony, imagine now that we adjourned to our conference room and talked among ourselves to arrive at a verdict. How plausible is it, in these discussions, that any of us would say: "The basic problem with these experiments is that the subjects did not agree to participate"? How truly important, or even relevant, was the question whether any subject had consented before his lungs were exploded in a high altitude chamber, before he was tossed into ice water until he froze to death, before he was burnt and left to die of infection, before his healthy arm was amputated to provide training experience for the surgeon? To insist on the importance, or even the relevance, of consent in these matters is surely peculiar. But the Nuremberg tribunal judges did indulge in this almost fantastic imagining. How could they have come to this? After hearing about these barbaric experiments for 133 days, how could they begin their judgment by proclaiming that their primary standard of moral evaluation was: "The voluntary consent of the human subject is absolutely essential"?

There is a plausible answer to this question, but it is a disturbing answer. This answer is that other imaginable criteria offered no comfort for the future. The fact was, as the 133 days of testimony clearly demonstrated, that these experiments had been approved and carried out by recognized leaders of the German medical profession, by holders of university chairs, by respected teachers and researchers of worldwide reputation. In the face of this social reality, other more apparently plausible condemnatory criteria-in particular, the criteria subsequently set out in the tribunal's judgment that good physicians never purposefully inflict death or disabling injury on anyone-lacked convincing effective force.

Considerable effort was expended after the war, both inside and outside Germany, to claim that the physicians in the Nuremberg dock were not well-respected scientists and that the Nuremberg experiments were not "good science" or "real science." This effort cannot withstand critical scru- tiny. ${ }^{4}$ But the Nuremberg judges did not in any event pursue this chimera; they followed a different strategy. They did not put their trust in the existence of "civilized standards" among future professionals-neither in doctors who might consider whether to perform experiments nor in government officials who might prospectively or retrospectively judge the propriety of those experiments. The Nuremberg judges established, as their first line of defense against recurrence of these barbarities, the individual subject-patient armed with the principle of self-determination.

The implicit lesson that the Nuremberg judges drew from the trial testimony was that they could not place principal reliance on the self-restraining decency of traditional embodiments of social authority. This was the lesson taught not only by the doctors' trial but by the preceding war crimes trials of high government officials. The Nuremberg judges were led to their reliance on the protection of individual self-determination by the same route that had conveyed Thomas Hobbes to this conclusion three centuries earlier. Sitting in Nuremberg in 1947-surrounded by the physical wreckage of war and confronted by a human spiritual degradation beyond any previous experience-the judges could readily have imagined themselves plunged into Hobbes's state of nature where no one could trust another for protection or comfort; a time without social bonds, a "war of all against all" where everyone was at the mercy of others' unconstrained avarice and aggression. As Hobbes had seen in the aftermath of the seventeenth-century English civil war, the only predictable source for human protection in such a world was each individual's solitary instinct for self-preservation.

Hobbes also saw that perpetual warfare, where each individual could rely only on himself, was an intolerable state for human affairs since life would necessarily be without valued meaning, would be "nasty, brutish and short." We need not endorse Hobbes's proposed solution, that each of us should enter a social contract surrendering personal authority to one absolute sovereign, to understand the powerful truth in his diag- 
nosis that this endless sense of personal vulnerability and consequent perpetual wariness in all human relations is unbearable. But this unendurable world is precisely what the judges at Nuremberg glimpsed-and then tried strenuously to avoid. ments hovers in the background of these cases in the image of predatory doctors subjecting vulnerable people to inhumane scientific procedures in order to benefit some dogmatic social policy unrelated to the individual welfare of their patient-subjects.

If we look closely at contemporary American invocations of the self-determination ideal in doctor-patient relations, we can see the same underlying sense of betrayal and helpless vulnerability that framed the Nuremberg judgment.

If we look closely at contemporary American invocations of the self-determination ideal in doctor-patient relations, we can see the same underlying sense of betrayal and helpless vulnerability that framed the Nuremberg judgment-and even implicit parallels with the German concentration camp experiments in the expressed fears that medical technology imprisons and inflicts torture on many people. This nightmare vision was epitomized in the first state court case to apply the self-determination ideal specifically regarding the regulation of death in doctor-patient relations. In 1976, the New Jersey Supreme Court invoked this principle to free Karen Ann Quinlan, a young woman in a persistent vegetative state, from the mechanical respirator that apparently was keeping her indefinitely but insensibly alive. ${ }^{5}$ The U.S. Supreme Court effectively endorsed this precedent in 1990, in a case like Quinlan involving an unconscious young woman. ${ }^{6}$ In separate opinions, two justices testified to this same bad dream: "a seriously ill or dying patient whose wishes are not honored may feel a captive of the machinery required for life-sustaining measures" (Justice O'Connor) (p. 288); "the thought of an ignoble end, steeped in decay, is abhorrent" (Justice Brennan) ( $p$. $310)$. The shadow of the Nazi experi-
In these cases, as in the Nuremberg judgment itself, the triumphalist recitation of the self-determination ideal masks several nagging background questions: How did these once-trusted caretakers become transformed into heartless predators? If they no longer can be trusted to protect vulnerable people, who can be trusted? Can I trust no one but myself when I am helplessly vulnerable? And, even more poignantly, is it enough to trust myself when I am helplessly vulnerable? To understand the self-determination ideal not as a transhistorical postulate but as the answer offered to these questions, questions that erupted urgently in a specific cultural and historical context, is to see the fragility and pathos that underlies our contemporary invocation of the ideal of self-determination.

This is our full connection with Nuremberg, a genealogy that is suppressed but nonetheless implicitly conveyed beneath the surface of our constant repetition of the triumphalist version of this family history. There is, however, a substantial cost to this mode of recollection, this unmentioned but nonetheless atmospherically conveyed dark suspicion of weakness that underlies our protestations of confident strength. The most compelling contemporary expression of this suppressed recollection is in the arguments for a right to physicianassisted suicide. The proponents of this right base their claim on the principle of patient self-determination. But the invocation of this principle in this context carries the darker aspects of Nuremberg along with the text of the tribunal's judgment. Just as the Nuremberg citation to self-determination did not resolve the issue before the tribunal, since the subjects' consent to the experiments would not have justified them, so too the selfdetermination principle is radically incomplete as a justification for physician-assisted suicide. In both contexts, the confident assertion of the self-determination right leaves unacknowledged and unanswered a crucial background question: who can be trusted to care for me when I am too vulnerable and fearful to care for myself?

The self-determination principle cannot answer this question since the question itself rests on the premise that the subject is too weak for effective self-protection. In the context of physician-assisted suicide, this unasked question arises in the gap between the professed principle of selfdetermination and the demand for the assistance of another person, a professional caretaker, to carry out the subject's wishes. If self-determination truly were the core value at issue in this demand, then the practicably available and legally recognized opportunities for self-administered suicide would have an obvious relevance. For terminally ill, mentally competent people in particular-the group for whom the right is exclusively claimed in the current cases - existing law already provides the option not only of refusing high-technology life-prolonging treatment but also food and water. And when a terminally ill, mentally competent person makes this choice, existing law does not bar physicians from providing palliative care which, well within current technological capacity but without purposefully has tening death, can effectively address any physical discomforts that might accompany this path toward death.

The exercise of this option, which is fully justified by the internal logic of the self-determination principle, is not, however, enough for the current claimants. They want more than self- 
determination. They want active assistance from physicians. They want active support from state officials in order to assure that physicians will care for them. They want a reassuring answer to the question that hovered behind the Nuremberg doctors' trial: whether physicians and/or state officials can be trusted to protect rather than abuse vulnerable people. The principle of self-determination was invoked by the Nuremberg judges in effect to mask the fact that they could not provide any reassuring answer. The same principle is also invoked today, most notably though not exclusively in the claims for physicianassisted suicide, more as an expression of mistrust toward physicians and the state than as a convincing refutation of that mistrust.

The staggering fact about our contemporary comprehension of the Nazi era in Germany is that we still cannot understand how and why it happened-whether it reflects some deep fault line in German character, in modern technological societies, in human nature; whether it was a unique historical event produced by a combination of forces unlikely to come together again, or whether its preconditions are readily replicable; whether any possible repetition can be averted by self-consciously devised preventive measures and, if so, precisely what those administrations might be. These large, terrible, unanswered questions are the full legacy of the Nuremberg trials. We are walking through these questions today in the specific context of claims for physician-assisted suicide. No wonder that a hasty conclusion, even a quick death, might appear preferable to an answer that we do not want to hear.

\section{References}

1. For example, Justice O'Connor's concurring opinion in Washington $\mathbf{v}$. Harper, 494 U.S. 210, 238 (1990); Justice
Brennan's separate opinion in United States v. Stanley, 483 U.S. 669, 687 (1987).

2. See Jay Katz, "The Consent Principle of the Nuremberg Code: Its Significance Then and Now," in The Nazi Doctors and the Nuremberg Code, ed. George J. Annas and Michael A. Grodin (New York: Oxford University Press, 1992), pp. 227-38.

3. "Judgment and Aftermath," The Nazi Doctors, pp. 94-107.

4. See Robert N. Proctor, "Nazi Doctors, Racial Medicine, and Human Experimentation," The Nazi Doctors, pp. 18-31; Christian Pross, "Nazi Doctors, German Medicine, and Historical Truth," The Nazi Doctors, pp. 32-52; Mario Biagioli, "Science, Modernity, and the 'Final Solution', in Probing the Limits of Representation: Nazism and the "Final Solution," ed. S. Friedlander (Cambridge: Harvard University Press, 1992), pp. 185-205, at 185.

5. In re Quinlan, 70 N.J. 10, 355 A.2d 647 (1976).

6. Cruzan v. Director, Missouri Department of Health, 497 U.S. 261 (1990).

7. See Compassion in Dying v. Washington, 79 F.3d 790 (9th Cir. 1996); Quill v. Vacco, 80 F.3d 716 (2d Cir. 1996). 